\title{
RELEVANSI MATERI MATA KULIAH FISIKA TEKNIK DAN KIMIA TEKNIK DENGAN MATERI MKKBS PRODUKSI DAN PERANCANGAN DI DPTM FPTK UPI
}

\author{
Setiawan Hidayat ${ }^{1}$, Amay Suherman ${ }^{2}$, Aam Hamdani ${ }^{3}$ \\ Departemen Pendidikan Teknik Mesin \\ Universitas Pendidikan Indonesia \\ Jl. Dr. Setiabudhi No. 207 Bandung 40154 \\ Setiawanhidayat90@gmail
}

\begin{abstract}
ABSTRAK
Penelitian ini bertujuan untuk menghasilkan deskripsi relevansi materi dan pemetaan sekuen antara materi mata kuliah fisika dan kimia teknik dengan materi mata kuliah keahlian bidang studi (MKKBS). Metode yang digunakan adalah metode deskriptif analitik dengan teknik pengumpulan data dokumentasi, wawancara, dan angket. Hasil penelitian menunjukkan bahwa ada MKKBS yang memerlukan dukungan seluruh materi mata kuliah fisika dan kimia teknik. Ada MKKBS yang sama sekali tidak memerlukan dukungan materi mata kuliah fisika dan kimia teknik. Materi mata kuliah fisika dan kimia teknik yang tidak diperlukan pada MKKBS bukan berarti harus dihilangkan, melainkan harus tetap ada untuk mendukung MKKBS lainnya. Mata kuliah fisika teknik belum sepenuhnya mendukung seluruh materi yang diperlukan oleh MKKBS. Materi mata kuliah kimia teknik sudah sepenuhnya mendukung materi yang diperlukan oleh MKKBS. Diperoleh dokumen pemetaan sekuen relevansi materi mata kuliah fisika teknik dan kimia teknik dengan materi MKKBS.
\end{abstract}

Kata kunci: relevansi, fisika, kimia, perancangan, produksi.

\begin{abstract}
The aims of the study is to produce description of materials relevance and mapping of sequences between materials course physics and chemical engineering with the material core subjects field of study (MKKBS). The method used is descriptive analytical method with data collection in the form of technical documentation, interviews, and questionnaires. The results showed that there MKKBS which requires the support of all course materials physics and chemical engineering, and there is also MKKBS totally not require support course materials physics and chemical engineering. Physics and chemical engineering course materials are not required to MKKBS not meant to be removed, but must remain there to support other MKKBS. Referring to the results of these studies, physics engineering courses not fully support all of the material that is required by MKKBS, whereas chemical engineering courses has been fully supports all of the material that is required by MKKBS, but it also obtained a document mapping of sequences between materials course physics and chemical engineering with the material MKKBS.
\end{abstract}

Keywords: relevance, physics, chemical, designing, production

\footnotetext{
${ }^{1}$ Mahasiswa Departemen Pendidikan Teknik Mesin FPTK UPI

${ }^{2}$ Dosen Departemen Pendidikan Teknik Mesin FPTK UPI

${ }^{3}$ Dosen Departemen Pendidikan Teknik Mesin FPTK UPI
} 


\section{PENDAHULUAN}

Penelitian mengenai relevansi materi mata kuliah Fisika Teknik dengan materi Mata Kuliah Keahlian Bidang Studi (MKKBS) pernah dilakukan pada tahun 1996/1997, selanjutnya diperbarui kembali pada tahun 2003. Namun demikian, penelitian tersebut tidak terdokumentasi dengan baik, sehingga hasilnya tidak dapat diketahui. Sementara itu, penelitian mengenai relevansi materi mata kuliah Kimia Teknik dengan MKKBS belum pernah dilakukan. Setiap rapat pelaksanaan kurikulum yang diadakan oleh Departemen Pendidikan Teknik Mesin (DPTM), FPTK UPI, khususnya pada Kelompok Bidang Keahlian (KBK) Produksi dan Perancangan (PP) selalu dibahas mengenai relevansi antar mata kuliah. Akan tetapi belum pernah dilakukan pembahasan sampai pada tahap relevansi antar materi mata kuliah. Padahal, relevansi materi antar mata kuliah dapat mempengaruhi Kegiatan Belajar Mengajar (KBM). Pada saat KBM dosen pengampu mata kuliah fisika dan kimia teknik sudah pernah mengilustrasikan pengaplikasian materi ajarnya pada materi MKKBS, namun masih sedikit materi yang diilustrasikan, sehingga mahasiswa tidak memperoleh gambaran pengaplikasian yang jelas dan variatif dari setiap materi yang telah diterima.

Dokumen relevansi materi mata kuliah fisika dan kimia teknik dengan materi MKKBS sangat diperlukan untuk melihat sejauh mana gambaran keterkaitan antar materi pada setiap mata kuliah, karena dalam kurikulum harus ada kesesuaian antara komponen kurikulum, khususnya isi/materi mata kuliah. Selain itu, dokumen kurikulum juga dapat membantu dosen pengampu mata kuliah fisika teknik, kimia teknik dan MKKBS dalam KBM untuk memberi penekanan-penekanan khusus pada materi-materi yang memiliki keterkaitan. Imbasnya, mahasiswa dapat memahami dengan jelas pengaplikasian materi yang telah diterima dalam perkuliahan. Berdasarkan hal tersebut, penelitian ini dilakukan untuk menghasilkan deskripsi relevansi materi dan pemetaan sekuen antara materi mata kuliah fisika dan kimia teknik dengan materi MKKBS Produksi dan Perancangan.

Kurikulum relevansi merupakan salah satu prinsip umum pengembangan kurikulum yang meliputi prinsip relevansi eksternal dan prinsip relevansi internal. Menurut Kurniawan prinsip relevansi eksternal merupakan kesesuaian antara kurikulum dengan tuntutan dan kebutuhan masyarakat, sedangkan prinsip relevansi internal merupakan kesesuaian antar komponen kurikulum itu sendiri (Ibrahim et al., 2011:67). Oleh karena itu, relevansi yang terjadi antara materi mata kuliah Fisika Teknik dan Kimia Teknik dengan materi MKKBS jika dikaitkan dengan pendapat Kurniawan tersebut termasuk dalam prinsip relevansi internal. 
Pada buku Pedoman Pengembangan Kurikulum UPI, Tim Pengembang Kurikulum (2013:10) menyatakan bahwa koherensi atau relevansi dalam konten kurikulum pendidikan guru bermakna adanya keterkaitan diantara kelompok mata kuliah bidang studi (content knowledge). Oleh karena itu, materi mata kuliah fisika dan kimia teknik dengan materi MKKBS harus memiliki kohenrensi dan senantiasa dipantau serta dievaluasi, sehingga tujuan pendidikan yang diharapkan dapat tercapai dengan baik. Sebagaimana yang disampaikan oleh Ibrahim bahwa evaluasi dalam kurikulum berperan untuk mengetahui efektivitas pencapaian tujuan pendidikan (Ibrahim et al., 2011:46). Dari pendapat tersebut dapat dipahami bahwa perubahan dalam arti pengembangan kurikulum perlu dilakukan untuk mengetahui sejauh mana ketercapaian tujuan pendidikan, khususnya tujuan DPTM dan untuk menyesuaikan dengan keadaan yang sedang berlangsung. Nasution pernah mengatakan bahwa kurikulum dapat diartikan sebagai sesuatu yang hidup dan berlaku selama jangka waktu tertentu dan perlu direvisi secara berkala agar tetap relevan dengan perkembangan zaman (Nasution, 2009:121). Lebih dari itu, beliau menyampaikan degan tegas bahwa mempertahankan kurikulum yang ada akan merugikan anak-anak dan fungsi kurikulum itu sendiri (Nasution, 2009:252). Oleh karena itu, perubahan atau perbaikan yang terjadi pada kurikulum adalah suatu kepastian yang tidak dapat ditolak.

Mengembangkan kurikulum harus memperhatikan prinsip-prinsip pengembangan kurikulum dan organisasi kurikulum. Prinsip-prinsip pengembangan kurikulum terdiri dari prinsip umum dan prinsip khusus. Prinsip umum tidak dipengaruhi oleh tempat dan situasi yang terjadi sedangkan pirnsip khusus selalu dipengaruhi oleh tempat dan situasi yang terjadi. Sementara itu, organasisi kurikulum merupakan desain isi/materi dalam kurikulum. Untuk mendesain isi/materi kurikulum harus mempertimbangkan prinsip-prinsip yang menyertainya, sebagaimana yang dikemukakan oleh Ibrahim yaitu prinsip yang berkaitan dengan ruang lingkup (scope), urutan bahan (sequence), kontinuitas, keseimbangan, dan keterpaduan (integrated) ( Ibrahim et al., 2011:88). Berkenaan dengan sequence, Arifin memperjelas bahwa urutan bahan adalah penyusunan materi pelajaran menurut aturan dan sistematika tertentu secara berurutan, biasanya dari yang mudah sampai yang sulit, dari yang sederhana sampai yang kompleks, dari keseluruhan sampai bagian-bagian, dari dahulu hingga sekarang (kronologis), dan dari yang konkret menuju yang abstrak (Arifin, 2012:90). 


\section{METODE PENELITIAN}

Metode peneletian yang digunakan adalah metode deskriptif analitik untuk mengetahui gambaran relevansi materi mata kuliah Fisika Teknik dan Kimia Teknik dengan materi MKKBS di KBK PP. Dalam penelitian ini tidak ada perlakuan (treatment) tertentu pada data yang telah terkumpul, sehingga data tersebut hanya dideskripsikan apa adanya dan disimpulkan secara khusus (tidak menggenerelisasi). Penelitian ini dilakukan dengan beberapa tahapan, yaitu tahap pra-lapangan, pekerjaan lapangan, dan analisis data. Tahap pra-lapangan meliputi studi pendahuluan dengan melakukan wawancara dengan responden untuk memperjelas permasalahan yang diteliti, merancang metodologi penelitian yang sesuai dengan permasalahan yang diteliti, studi dokumentasi dengan mempelajari dokumen kurikulum 2013 DPTM, menyusun instrumen penelitian berupa lembar wawancara dan angket, serta membuat kesepakatan waktu dan tempat dengan responden mengenai kesediaan untuk memberikan data dan informasi. Sementara itu, tahap pekerjaan lapangan meliputi wawancara dengan responden untuk mengecek kesesuaian silabus mata kuliah dan memperoleh informasi mengenai silabus mata kuliah, menyebarkan angket kepada responden, memeriksa kelengkapan jawaban dalam angket, dan memeriksa jumlah lembaran angket yang telah terkumpul, selanjutnya tahap analisis data meliputi pengolahan data dengan menghitung keperluan materi mata kuliah fisika dan kimia teknik untuk MKKBS, menganalisis dan melakukan pembahasan terhadap hasil pengolahan data, serta membuat kesimpulan dan saran penelitian.

\section{HASIL PENELITIAN}

Materi mata kuliah fisika teknik terdiri dari 13 materi, yaitu: (1) Besaran, Satuan, dan Vektor; (2) Kinematika Partikel; (3) Dinamika Partikel; (4) Usaha dan Energi; (5) Momentum, Impuls, dan Tumbukan; (6) Benda Tegar; (7) Elastisitas; (8) Getaran dan Gelombang; (9) Listrik Statis; (10) Listrik Dinamis; (11) Kemagnetan; (12) Imbas Elektromagnetik; dan (13) Arus Bolak-Balik, sedangkan materi mata kuliah Kimia Teknik terdiri dari tujuh materi, yaitu: (1) Konsep Dasar Kimia; (2) Stokiometri; (3) Persamaan Reaksi Kimia; (4) Sistem Periodik Unsur-Unsur; (5) Termokimia; (6) Elektrolit dan Elektrokimia; dan (7) Aplikasi Kimia dalam Bidang Teknik Mesin. Selanjutnya, materi mata kuliah fisika dan kimia teknik tersebut direlevansikan dengan materi MKKBS, sehingga akan terpetakan dengan jelas relevansinya.

Berdasarkan hasil pengolahan data relevansi antara materi mata kuliah fisika dan kimia teknik dengan materi MKKBS, diperoleh informasi bahwa ada MKKBS yang 
memerlukan dukungan ke-13 materi mata kuliah fisika teknik dan ketujuh materi mata kuliah kimia teknik, kemudian ada MKKBS yang memerlukan dukungan sebagian materi mata kuliah fisika dan kimia teknik, dan ada juga MKKBS yang sama sekali tidak memerlukan dukungan materi mata kuliah fisika dan kimia teknik. MKKBS yang memerlukan dukungan ke-13 materi mata kuliah Fisika Teknik adalah mata kuliah Material Teknik Lanjut, sedangkan MKKBS yang memerlukan dukungan ketujuh materi mata kuliah Kimia Teknik adalah mata kuliah Termodinamika Teknik, Korosi dan Pelapisan Logam, Material Teknik Lanjut, dan Teknik Penyambungan.

Sementara itu, MKKBS yang memerlukan sebagian materi mata kuliah fisika teknik yaitu material teknik, gambar teknik, termodinamika teknik, mekanika teknik, teknik listrik dan elektronika, pengerjaan logam, korosi dan pelapisan logam, konversi energi, perpindahan panas, kinematika dinamika, elemen mesin, pneumatik hidrolik, pemesinan dasar, CAD dan gambar mesin, teknik pengelasan dasar, pemrograman komputer, CNC dasar, teknik pembentukan, teknik pengecoran, otomasi, pemesinan khusus, teknik penyambungan, dan teknik pengecoran lanjut. MKKBS yang memerlukan sebagian materi mata kuliah kimia teknik, yaitu material teknik, gambar teknik, mekanika teknik, teknik listrik dan elektronika, pengerjaan logam, konversi energi, perpindahan panas, kinematika dinamika, elemen mesin, pneumatik hidrolik, pemesinan dasar, teknik pengelasan dasar, teknik pembentukan, teknik pengecoran, pemesinan khusus, kewirausahaan, dan teknik pengecoran lanjut. Selanjutnya, MKKBS yang tidak memerlukan dukungan materi mata kuliah fisika teknik adalah mata kuliah statistika terapan, pengendalian mutu, manajemen produksi, manajemen sumber daya manusia, dan kewirausahaan. MKKBS yang tidak memerlukan dukungan materi mata kuliah kimia teknik adalah mata kuliah statistika terapan, pengendalian mutu, CAD dan gambar mesin, manajemen produksi, manajemen sumber daya manusia, pemrograman komputer, CNC dasar, dan otomasi. Relevansi materi Mata Kuliah Fisika Teknik dan Kimia Teknik dengan materi MKKBS dapat dilihat pada Gambar 1 dan 2.

Hasil temuan penelitian yaitu ada MKKBS yang memerlukan tambahan materi lain (di luar ke-13 materi) pada mata kuliah fisika teknik untuk mendukung materi MKKBS tersebut, yaitu mata kuliah korosi dan pelapisan logam serta mata kuliah otomasi. mata kuliah korosi dan pelapisan logam memerlukan tambahan materi rectifier (alat pengubah arus AC menjadi Arus DC), sedangkan mata kuliah otomasi memerlukan materi arus searah (DC) dan metode pengubah arus AC menjadi DC. 


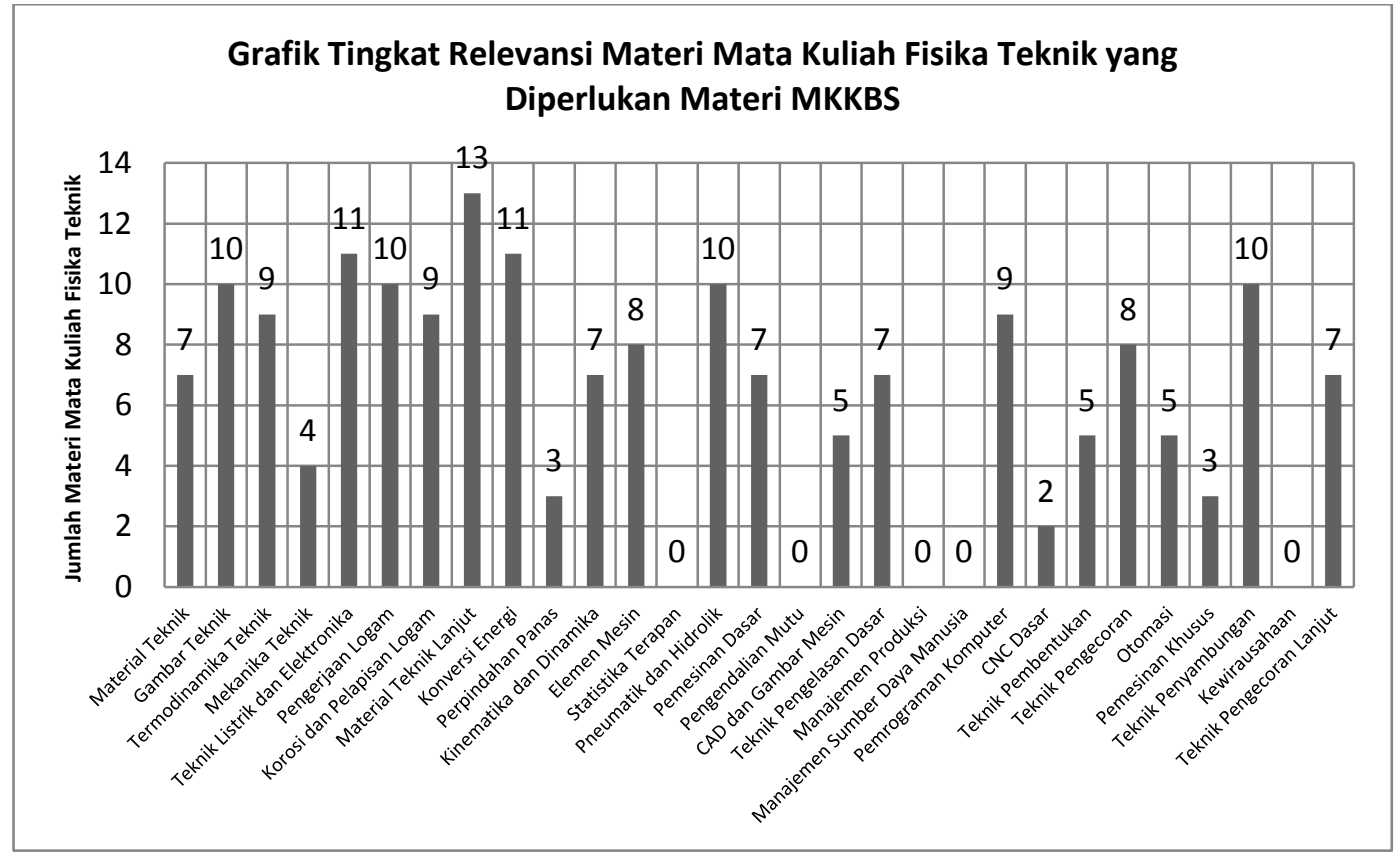

Gambar 1. Relevansi materi mata kuliah fisika teknik yang diperlukan MKKBS

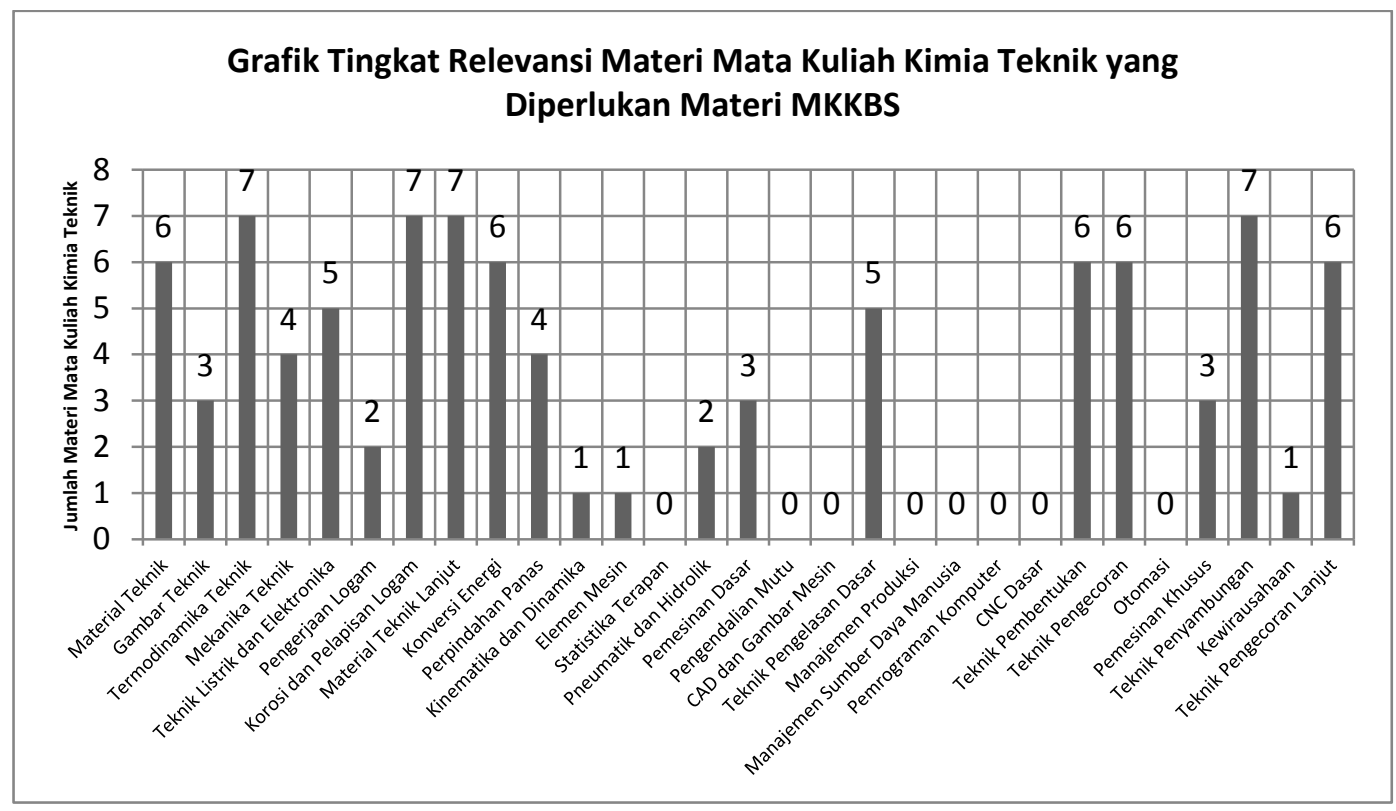

Gambar 2. Relevansi materi mata kuliah kimia teknik yang diperlukan MKKBS.

\section{PEMBAHASAN}

Materi mata kuliah fisika teknik yang berjumlah 13 materi terpetakan kesemua MKKBS kecuali pada mata kuliah statistika terapan, pengendalian mutu, manajemen produksi, manajemen sumber daya manusia, dan kewirausahaan. begitu pula halnya materi 
mata kuliah kimia teknik yang berjumlah tujuh materi terpetakan kesemua MKKBS kecuali pada mata kuliah statistika terapan, pengendalian mutu, CAD dan gambar mesin, manajemen produksi, manajemen sumber daya manusia, pemrograman komputer, CNC dasar, dan otomasi. materi pada mata kuliah fisika teknik dan kimia teknik yang tidak terpetakan pada MKKBS adalah materi yang tidak diperlukan MKKBS.

Materi-materi pada mata kuliah fisika dan kimia teknik yang tidak diperlukan pada MKKBS bukan berarti harus ditiadakan atau dihilangkan, akan tetapi ada dua kemungkinan yang harus dipertimbangkan. Kemungkinan pertama, materi-materi yang tidak diperlukan tersebut adalah prasyarat sebelum mempelajari materi-materi yang mendukung materi MKKBS, contohnya materi listrik statis pada mata kuliah fisika teknik merupakan prasyarat untuk mempelajari materi listrik dinamis yang mendukung materi perencanaan clutch pada mata kuliah elemen mesin. Kemungkinan kedua, materi-materi yang tidak diperlukan tersebut adalah materi yang mendukung materi pada MKKBS lainnya. Hal ini, karena dalam penyusunan materi mata kuliah fisika dan kimia teknik, dosen pengampu tidak hanya menyusun materi untuk mendukung satu MKKBS, tetapi untuk seluruh MKKBS, misalnya materi arus bolak-balik pada mata kuliah fisika teknik tidak mendukung mata kuliah elemen mesin, akan tetapi materi tersebut mendukung materi konsep kontrol otomasi di industri pada mata kuliah pneumatik dan hidrolik.

Menyusun materi mata kuliah dosen pengampu mata kuliah fisika dan kimia teknik tentu berkoordinasi terlebih dahulu dengan dosen pengampu MKKBS dan DPTM, sehingga penyusunan materi tersebut mengacu pada suatu aturan dan sistematika tertentu yang telah ditetapkan. Hal ini sesuai dengan yang disampaikan oleh Arifin (2012:90) bahwa penyusunan materi pelajaran menurut aturan dan sistematika tertentu secara berurutan, biasanya pengembang kurikulum berpegang pada urutuan dari yang mudah sampai yang sulit, dari yang sederhana sampai yang kompleks, dari keseluruhan sampai bagian-bagian, dari dahulu hingga sekarang (kronologis), dan dari yang konkret menuju yang abstrak.

Penyusunan materi mata kuliah fisika dan kimia teknik merupakan desain atau rancangan isi/materi kurikulum (organisasi kurikulum), sehingga dalam metakan setiap materi mata kuliah tidak bisa secara apa adanya (tidak sistematis), akan tetapi harus memperhatikan prinsip-prinsip dalam mendesain isi kurikulum. Sebagaimana yang disampaikan oleh Ibrahim et al. (2011:88) bahwa prinsip dalam organisasi kurikulum diantaranya berkaitan dengan ruang lingkup (scope), urutan bahan (sequence), kontinuitas, keseimbangan, dan keterpaduan (integrated). 
Mengacu pada prinsip relevansi internal yang disampaikan Sukmadinata dan dikutip oleh Suciari (2014:9) bahwa relevansi internal merupakan kesesuaian antar komponen kurikulum itu sendiri, maka relevansi materi mata kuliah fisika teknik dengan materi MKKBS belum terpenuhi seutuhnya. Hal ini karena ada materi yang diperlukan MKKBS tetapi belum tercantum pada ke-13 materi mata kuliah fisika teknik. Sementara itu, relevansi antara materi mata kuliah kimia teknik dengan materi MKKBS sudah terpenuhi seutuhnya, karena tidak ada materi lain yang perlu ditambahkan.

Data hasil penelitian relevansi materi mata kuliah fisika dan kimia teknik dengan materi MKKBS merupakan implementasi dari pengembagan kurikulum, sehingga dapat dievaluasi seberapa jauh tingkat relevansi masing-masing mata kuliah tersebut. Terukurnya dan terpetakannya materi mata kuliah fisika dan kimia teknik kesemua MKKBS menjadi bahan evaluasi penting bagi DPTM untuk perbaikan dan pengembangan kurikulum kedepannya, khususnya dalam mewujudkan tujuan DPTM. Hal ini sebagaimana yang disampaikan oleh Ibrahim et al. (2011:46) bahwa evaluasi dalam kurikulum berperan untuk mengetahui efektivitas pencapaian tujuan pendidikan. Namun demikian, perlu diingat bahwa tidak selamanya perbaikan dan perubahan akan membawa kebaikan pada keadaan. Sesuai dengan yang dinyatakan oleh Nasution bahwa perbaikan berarti meningkatkan nilai atau mutu, sedangkan perubahan adalah pergeseran posisi, kedudukan atau keadaan yang mungkin membawa perbaikan, akan tetapi dapat juga memperburuk keadaan (Nasution, 2009:122).

Oleh karena itu, setiap perbaikan maupun perubahan pada kurikulum harus senantiasa berorientasi pada tujuan pendidikan dan prinsip-prinsip yang menyertainya. Jatmoko (2013:5) menerangkan prinsip-prinsip yang menyertai kurikulum mengacu pada pendapat Sukmadinata yaitu: (1) prinsip-prinsip umum: relevansi, fleksibilitas, kontinuitas, praktis, dan efektivitas; (2) prinsip-prinsip khusus: prinsip berkenaan dengan tujuan pendidikan, prinsip berkenaan dengan pe-milihan isi pendidikan, prinsip berkenaan dengan pemilihan proses belajar mengajar, prinsip berkenaan dengan pemilihan media dan alat pelajaran, dan prinsip berkenaan dengan pemilihan kegiatan penilaian. Selain itu, Saripati menambahkan bahwa kurikulum pendidikan harus komprehensif dan responsif terhadap dinamika sosial, relevan, tidak over load dan mampu mengakomodasikan keberagaman dan kemajuan teknologi (Deni Ramdani S., Suwachid, dan Estriyanto Y., 2012:57). 


\section{KESIMPULAN}

Mengacu pada prinsip relevansi internal, materi mata kuliah fisika teknik yang berjumlah 13 materi belum sepenuhnya mendukung seluruh materi yang diperlukan oleh MKKBS. Perlu ada penambahan dua materi lainnya supaya dapat mendukung seluruh materi yang diperlukan oleh MKKBS. Sementara itu, materi mata kuliah kimia teknik yang berjumlah 7 materi sudah sepenuhnya mendukung seluruh materi yang diperlukan oleh MKKBS. Dengan demikian, telah dihasilkan pemetaan sekuen antara materi mata kuliah fisika dan kimia teknik dengan materi MKKBS pada KBK PP, sehingga diperoleh gambaran dalam menentukan prasyarat mata kuliah.

\section{DAFTAR PUSTAKA}

Arifin, Z. (2012). Konsep dan Model Pengembangan Kurikulum. Bandung: Remaja Rosdakarya.

Deni R, S., Suwachid, dan Estriyanto, Y. (2012). Relevansi Mata Kuliah Berkarya (MKB) Konsentrasi Mesin Otomotif pada Program Studi Pendidikan Teknik Mesin Universitas Sebelas Maret Surakarta dengan Kebutuhan Industri Jasa Otomotif dan Sekolah Menengah Kejuruan. dalam NOSEL Jurnal Ilmiah Pendidikan Teknik Mesin [Online], Vol 1 (1), p.9. Tersedia: http://jurnal.fkip.uns.ac.id/index.php/ ptm/article/view/1364/946 [27 Januari 2015].

Ibrahim, R. (2011). Kurikulum dan Pembelajaran. Jakarta: Rajagrafindo Persada.

Jatmoko, D. (2013). Relevansi Kurikulum SMK Kompetensi Keahlian Teknik Kendaraan Ringan Terhadap Kebutuhan Dunia Industri Di Kabupaten Sleman. Dalam Jurnal Pendidikan Vokasi [Online], Vol 3 (1), p.13. Tersedia: journal.uny.ac.id/index.php/ jpv/article/download/1572/1299 [27 Januari 2015]

Nasution, S. (2009). Asas-Asas Kurikulum. Jakarta: Bumi Aksara.

Suciari. (2014). Pengembangan Kurikulum. [Online]. Tersedia: http://www.academia.edu/ 6205478/Pengembangan_Kurikulum_1.[29 Januari 2015]

Tim Pengembang Kurikulum. (2013). Panduan Pengembangan Kurikulum Universitas Pendidikan Indonesia. Bandung: Universitas Pendidikan Indonesia. 